\title{
An Analysis of The Impact On ICERs Due To A Change In The Discount Rate From 5\% To 1.5\% A Kerfuffle Over Changes In CADTH Guidelines
}

Eric Nauenberg ( $\nabla$ eric.nauenberg@utoronto.ca )

University of Toronto https://orcid.org/0000-0002-6165-2083

Mofakhar Hussain

University of Toronto

Jennifer Guo

University of Toronto

\section{Research Article}

Keywords: Cost-Effectiveness, Comparisons, Guidelines

Posted Date: July 26th, 2021

DOI: https://doi.org/10.21203/rs.3.rs-683061/v1

License: (c) (1) This work is licensed under a Creative Commons Attribution 4.0 International License.

Read Full License 
An Analysis of the Impact on ICERs Due to a Change in the Discount Rate from 5\% to 1.5\%:

A Kerfuffle over Changes in CADTH Guidelines

December 2020

--Please do not cite, quote or circulate without permission of the author(s)--

Key Words: Cost-Effectiveness, Comparisons, Guidelines

Word Count, 2,969

JEL classification code: I18 - Health: Government Policy; Regulation; Public Health 


\section{Abstract:}

\section{Abstract:}

Background: In 2017, The Canadian Agency for Drugs and Technologies in Health (CADTH) made a large change in their Guidelines for the Economic Evaluation of Health Technologies, by decreasing the reference case discount rate from $5 \%$ to $1.5 \%$. This change may substantially impact the incremental cost-effectiveness ratios (ICERs) submitted to Canadian funding authorities. Since it is not required to include the 5\% discount rate in sensitivity analysis, decision makers may find comparing ICERS calculated at different time-points challenging.

Methods: This paper constructs look-up tables for making such comparisons under three scenarios that involve either constant costs and benefits and linear changes in costs and/or benefits over time.

Results: cost-benefit projections that most closely emulate patterns observed with surgical interventions often combined with short-term prescription drug therapies can produce ICERs that are over $30 \%$ higher when a $5.0 \%$ discount rate is applied in comparison to one at $1.5 \%$.

Conclusions: There are occasions when original data and methodologies are unavailable that can be leveraged for reanalysis when discount rates change. In the instance of the Canadian context, the recommended change in reference discount rate as of 2017 was substantial requiring methods for comparing cost-effectiveness analyses conducted both before and after the change in discount rate. This paper offers a method for making such comparisons. 


\subsection{Background:}

In the spring of 2017, the Canadian Agency for Drugs and Technologies in Health (CADTH) issued new guidelines for the economic evaluation of health technologies, last revised in 2006 [1]. Amongst the various changes, there was a major shift in the recommendations regarding the reference case rate at which to discount costs and benefits- from 5\% to $1.5 \%$ per annum. Partially owing to historically low rates of borrowing in financial markets, CADTH felt compelled to lower the discount rate substantially. This change is notable because it may substantially impact the magnitude of reference case incremental cost-effectiveness ratios (ICERs). For bodies charged with making funding recommendations, assessing the relative favorability of ICERs calculated both before and after the new guidelines is difficult, particularly since both the perceived and/or commonly accepted cost-effectiveness thresholds have not shifted and funding submissions often do not include sensitivity analyses that incorporate either the $1.5 \%$ and $5 \%$ discount rates. For instance, sensitivity analyses in funding submissions produced prior to 2017 are unlikely to include an ICER calculation at a $1.5 \%$ discount rate as there was no agency recommending such a rate at that time. Following the guideline change, sensitivity analyses may also be unlikely to include a 5\% discount rate as it is

not required by CADTH [1,2]. Lastly, the original models may no longer be accessible to make adjustments in parameters.

Beyond ICERs changing simply due to the new lower discount rate, the lower rate may incent changes to introductory prices depending on whether long-term benefits exceed or are less than downstream costs as perceived cost-effectiveness thresholds remain unchanged. This may have been a factor intermixed with finding no compelling argument for major change that has caused governing authorities worldwide to leave recommended discount rates largely unchanged in recent years $[3,4]$. With regard to making comparisons, the change in CADTH's 
reference case discount rate has created a kerfuffle regarding how to compare ICERs calculated before and after the change. Specifically, there are a number of issues to be considered in terms of three sources of variation: the time horizon over which ratios are calculated; the variation in the discount rate itself; and the pattern over time of incurring costs and accruing benefits. In this regard, interventions with higher long-term benefits relative to costs can result in increasingly favorable ratios in comparison to those produced under the previous discount rate. Interventions that exhibit modest increases in benefits over time with constant costs may exhibit only small changes in the calculated ICER with the new lower discount rate; however, this depends on how steep the benefit gradient is. This paper explores the first three of six possible scenarios: 1) constant costs and benefits over time common to pharmaceuticals for chronic conditions (e.g., statins) [5]; 2) front-loaded cost streams with a constant stream of benefits often found with regard to surgical interventions often combined with short-term drug therapies; 3) a constant stream of costs with a modest upward linear trend in incremental benefits (e.g., prescription drugs in the mental health arena or anti-viral medications) [6]; (4) increasing non-linear incremental benefits (e.g., drug eluting stents) [7] (5) decreasing nonlinear incremental benefits (e.g., HPV vaccine) [8] and (6) a trend of increasing non-linear incremental benefits followed by decreasing non-linear incremental benefits (e.g., some of the treatments for drug addiction, Parkinson's Disease, certain cancer medications or various immunosuppressant medications) $[9,10,11]$. For scenario one, no cross-tabulations are necessary as this scenario is unaffected by changes in either the discount rate or time horizon. For scenarios two and three involving increasing and decreasing linear trends, a series of look-

\section{up tables of comparative values are produced.}

\subsection{Literature Review:}

Examination of guidelines produced by various HTA governing bodies suggests that 
there are various methods and underlying views that factor into determining the discount rates in each jurisdiction. A commonly prescribed perspective is to set a discount rate that reflects the real interest rate of low-risk investment, such as long-term government bonds $[1,12,13]$. Other alternatives include adopting a social rate of time preference (SRTP), which is used by governments to determine the investment value of other public-sector projects, programs, and policies $[14,15,16]$. The majority of jurisdictions recommend applying the same discount rate to both costs and health outcomes [17,18]. Select guidelines, however, permit the consideration of a differential rate under certain scenarios - for example, when there is evidence that the preference for the present value of health outcomes and costs is different, such as when long-term health benefits are substantial [19,20]. However, only Belgium, the Netherlands and Poland explicitly recommend a lower discount rate for health outcomes than for costs arguing that, over time, the willingness to pay for health outcomes will vary and that the expected change of value of health outcomes is often uncertain. As such, it is important to avoid over-discounting interventions that generate benefits far into the future such that short-term interventions will not be disproportionally preferred over longer-term interventions [21,22].

It is acknowledged that the discount rate should be periodically reviewed and revised as appropriate to reflect the political and socioeconomic changes in society [23]. As such, in theory, the discount rate should vary by country $[12,21,24,25]$. In practice, however, few jurisdictions have chosen discount rates outside the 3\%-5\% range. Discount rates have also largely remained unaltered throughout guideline revisions and updates in most jurisdictions. Of the jurisdictions that have implemented changes to the discount rate overtime, they have been adjusted within \pm $0.5 \%$ to $1 \%$. Only Canada, France, and Germany have proceeded with a change in discount rate of $2 \%$ or greater.

Table 1 summarizes recommended discount rates for both reference cases and sensitivity 
analyses prescribed by HTA governing bodies internationally. Current and, if applicable, previous guidelines are listed. If available, the rationale for the chosen rates are also presented. Insert Table 1 here.

\subsection{Methods:}

For examining the impact of discount rates on the ICER, two steps are involved in scenarios involving linearly increasing and decreasing streams of benefits and costs. These steps include: (1) creating a number of scenarios for how benefits and costs accumulate over time; and (2) fashioning look-up tables to compare ICERs over the range of $\$ 5,000$ to $\$ 500,000$ per quality adjusted life year (QALY) with those calculated at different time horizons $-5,10$, and 20 years - and alternative discount rates $-1.5 \%, 3 \%, 4 \%$, and 5\%. Microsoft ${ }^{\circledR}$ Excel@ 2013 was used in the analysis [26].

Because non-constant linear streams of costs and benefits result in changes to the value of an ICER as the discount rate and time horizon changes, producing values for a look-up table will assist in the decision-making process. To do this, it is necessary to come up with a hypothetical cost-benefit profile, determine the ICER, and calibrate this value so that it can be aligned to a look-up table grid. This involves determining the ratio, $k$, of a hypothetical healthcare intervention's ICER (at a $1.5 \%$ discount rate) to calibrated reference case values that aligns to such a grid (e.g., \$5,000/QALY increments - see Appendix A). This ratio is needed to both produce scaled-up ICERs at different discount rates and to adjust values in the tables to any ICERs that fall between the set increments. Regardless of the hypothetical intervention chosen to generate the look-up tables, the calibration to the grid will provide approximate ICER comparison values for interventions with either of the two types of cost-benefit streams provided in Appendix A. Further, if the exact cost-benefit stream is available, a URL is provided to allow the user to input values alongside the requested discount rate and time horizon to obtain a more 
precise estimate.

The process of calibration involves two steps:

(1) A calibration factor is applied to an ICER at a discount rate of $1.5 \%$ under any particular time horizon. The result produces 100 ICERs, starting at $\$ 5,000 / \mathrm{QALY}$ to $\$ 500,000 / \mathrm{QALY}$, in increments of $\$ 5,000 / \mathrm{QALY}$.

(2) The calibrated incremental cost of the new technology is scaled according to different discount rates and time horizons.

Example: Produce comparison ICER to \$5,000/QALY reference case value under scenario (2) with five-year time horizon and $3 \%$ discount rate

STEP 1: Determining the calibration value under $1.5 \%$ discount rate

Given:

- Profile of incremental benefits and costs: 5 years--incurring costs over only the first two

- Discount rate: $1.5 \%$

- Total cost of an example technology: approximately $\$ 6,250$

- Incremental benefit per year: 0.25 QALYs

Discounted Benefits over five years: $\sum_{i=1}^{5} \frac{0.25 Q A L Y s}{1.015^{i}}=1.1957$ QALYs (QALYs calculated at end of every year for five years)

Discounted Costs over first two years : $\sum_{i=1}^{2} \frac{\$ 3,125}{1.015^{i}}=\$ 6,112$ (Costs calculated at end of every year for first two years)

Under this scenario, the ICER $=\frac{\$ 6,112}{1.1957 Q A L Y S}=\frac{\$ 5,112}{Q A L Y}$

To determine the adjustment to the actual ICER needed to produce a calibrated reference case

ICER (e.g., \$5,000/QALY), calculate the calibration factor: $k=\frac{\$ 5,112}{\$ 5,000}=1.0224$

The calculations for Step 1 are summarized in Table 2 below.

--Insert Table 2 here- 
Step 2: Determining calibrated ICER under 3\% discount rate

The present value of the stream of costs is given by $\sum_{i=1}^{2} \frac{\$ 3,125}{1.03^{i}}=\$ 5,980$ and the incurrence of discounted benefits over five years, $\sum_{i=1}^{5} \frac{0.25 Q A L Y s}{1.03^{i}}=1.1449$ QALYs.

$\operatorname{ICER}(3 \%$ discount rate $)=\frac{\$ 5,980}{1.1449 Q A L Y S}=\frac{\$ 5,223}{Q A L Y}$

The calibrated ICER at 3\% rate of discount associated with the calibrated reference case ICER of $\$ 5,000 / \mathrm{QALY}$ is calculated using the calibration factor

$\left(\frac{\$ 5,223}{Q A L Y}\right) / 1.0224=\frac{\$ 5,108}{Q A L Y S}$.

A similar method is applied for all ICER levels and across four- and five-percent rates of discount, and 10- and 20-year time horizons.

More generally,

Uncalibrated ICER $(\mathrm{i}, \mathrm{r}, \mathrm{t})=\frac{\sum_{i=1}^{t} \frac{C_{i}}{(1+r)^{i}}}{\sum_{i=1}^{t} \frac{Q A L Y}{(1+r)^{i}}}$

where $i$ represents a particular year in the stream of costs and benefits, and $r$ represents the discount rate calculated at the end of the year; $C_{i}$ represents incremental cost in year $i$, $Q A L Y_{i}$ represents the level of incremental benefit in year $i$, and $t$ represent length of time horizon over which costs and benefits are accrued. To adjust an uncalibrated ICER to produce a value for a look-up table, divide it by the calibration factor, $k$, for the technology under examination to align values to a look-up table grid ranging from $\$ 5,000$ to $\$ 500,000 / \mathrm{QALY}$ by $\$ 5,000 / \mathrm{QALY}$ increments.

Thus,

Calibrated ICER in look-up tables $=$ Un-calibrated ICER $/ k$ or conversely, un-calibrated 
ICER $=k *$ Calibrated ICERs in look-up tables.

\subsection{Results:}

\subsection{Scenario One.}

The first scenario involves a constant stream of costs and benefits over time with longer time horizons requiring lower annual costs and benefits to achieve the same magnitude ICER. A hypothetical example might be a constant annual stream of costs of $\$ 5,000$ and benefits of 0.25 QALYs per year of treatment. The ICER remains constant for a particular time-horizon regardless of discount rate as per equation (1); therefore, construction of a lookup table for this scenario is not necessary.

\subsection{Scenario Two.}

The second scenario involves all costs front-loaded in first two years and a constant stream of benefits as exhibited in Figure 1

\section{--Insert Figure 1 Here--}

Table 1A in Appendix A shows the results of a subset of the simulation from $\$ 30,000$ to \$150,000/QALY (full table available at https://docs.google.com/spreadsheets/ d/1FFa332qXtrtVXkdjE93ih4b4F--PIkiC_VMER48AHos/edit\#gid=1803679095). The ICERs become less favorable as both the time horizon and the discount rate increases. When decreasing the discount rate from 5\% to $1.5 \%$, the ICER decreases by $5.0 \%$ for a 5 -year time horizon, $13.5 \%$ for a 10 -year time horizon, and $31.0 \%$ for 20 -year time horizon. At a $1.5 \%$ discount rate and 5-year time horizon, an ICER of approximately \$50,000/QALY is associated with an ICER of $\$ 52,500 / \mathrm{Q} A L Y$ at a $5 \%$ discount rate. Shifting to a 20 -year time horizon produces an association between an ICER of $\$ 50,000$ and an ICER of $\$ 65,500 /$ QALY at corresponding discount rates. 


\subsection{Scenario Three.}

The third scenario involves constant costs with a modest increase in benefits at $5 \%$ per annum.

A hypothetical scenario fitting this description is contained in Figure 2.

.- Insert Figure 2 here--

Table 2A in Appendix A shows the results of a subset of the simulation from $\$ 30,000$ to

\$150,000/QALY (full table available at https://docs.google.com/spreadsheets/

d/1FFa332qXtrtVXkdjE93ih4b4F--PIkiC_VMER48AHos/edit\#gid=1803679095). The ICERs change

little in response to either longer time horizons or differing discount rates as the upward trend in benefits tends to compensate for the tendency for lower discount rates to increase ICERs when the stream of costs are constant. When decreasing the discount rate from $5 \%$ to $1.5 \%$, the ICER decreases by $2.1 \%$ for a 5 -year time horizon, $2.6 \%$ for a 10 -year time horizon, and $3.1 \%$ for 20 year time horizon. At a $1.5 \%$ discount rate and 5-year time horizon, an ICER of approximately $\$ 50,000 / \mathrm{QALY}$ is associated with an ICER of \$51,000/QALY. Shifting to a 20-year time horizon produces an association between an ICER of \$50,000 and an ICER of \$51,500/QALY at corresponding discount rates.

\subsection{Discussion and Conclusion:}

This analysis has shown that under certain circumstances, the decrease of the discount rate to $1.5 \%$ from $5 \%$ can have major changes on the value of an ICER, making it difficult to compare values obtained before and after the change in CADTH guidelines. The cost-benefit profile patterns that appears to exhibit the greatest change in ICERs across discount rates is when the incremental costs are front-loaded and there is a long-stream of constant, increasing, or decreasing incremental benefits. Such is the case regarding many health technology interventions in comparison to pharmaceutical products that have a more constant stream of costs 
and benefits over time. In the future, it might be possible to apply machine-learning algorithms to replicate non-linear trends in costs and benefits to provide simulations for scenarios four through six.

This paper provides both a formula to be applied to particular interventions under consideration and a series of sample lookup tables to better understand how the change in the discount rate can impact the value of an ICER. Both may help decision-makers by showing how ICERs compare between those calculated using a 5\%, 4\%, 3\% or $1.5 \%$ discount rate Ceteris paribus. Most obviously, the three examined scenarios cannot represent exactly every possible intervention and as such provide only approximate comparison values. It is also evident that there are other dynamics at play in response to the change in the discount rate for which these tables do not account, including how manufacturers and pharmaceutical companies may react price-wise to changes in the discount rate, given the pattern of costs and benefits over time that a particular product exhibits. Under certain cost-benefit profiles--with higher long-term benefits relative to costs--the move to a discount rate of $1.5 \%$ is potentially inflationary as manufacturers can meet perceived target ICER thresholds (e.g., \$50,000/QALY) with introductory prices that are higher than under previous guidelines [27].

With regard to the scenarios presented, streams of both costs and benefits are discounted at the end of each year of the intervention leading to a bias downward in the present value for both streams in comparison to discounting compounded continuously. However, both the numerator and denominator of an ICER are equally biased - regardless of the pattern of costs and benefits over time, the discount rate or the time horizon - making the choice of when to discount costs and benefits irrelevant for the calculation of these ratios.

With regard to the change in the discount rate itself, it is not clear that historically low rates of borrowing in financial markets are the appropriate barometer for making such a 
dramatic change in the rate. In a seminal paper examining this issue, Pauldin and colleagues (2016) suggest that possibly a non-constant discount rate may be more appropriate than a constant one given that there are different interest rates for securities with differing lengths of time to maturity. They argue that "If a social decision maker perspective is deemed to be appropriate, a pragmatic way forward might be for CADTH to adopt a non-constant discount rate that is common to all provinces" [28]. They suggest that such a rate is not without precedent, citing examples such as the U.S. Office of Management and Budget that requires cost-effectiveness analyses of federal projects discount benefits and costs at the real borrowing rate on marketable Treasury securities with period to maturity approximately the same as the designated analytical time horizon [29]. They further argue that the correct specification of a SRTP depends on evidence from: (a) per person consumption growth; (b) elasticities of marginal utility of consumption; (c) the level of social catastrophic risk; and (d) the social rate of pure time preference with regard to consumption [28]. They claim that while evidence for the first of these is available for Canada, the evidence for the remaining three are "...either of poor quality, highly uncertain, or absent" [28]. Thus, in the absence of strong evidence, the best choice may not have been to adopt a lower, constant discount rate, albeit the $5 \%$ rate was theoretically too high. In the meantime, while there are deliberations about further changes to these guidelines, the information contained in this paper may be useful to those trying to make sense of how ICERs calculated in previous years might compare to those calculated today and in the near future and vice versa. 
Table 1: Guidelines for Discount Rates (by Jurisdiction)

\begin{tabular}{|c|c|c|c|c|c|c|c|c|}
\hline \multicolumn{5}{|c|}{ Current Rate } & \multicolumn{4}{|c|}{ Previous Rate (if different from Current Rate) } \\
\hline $\begin{array}{l}\text { Country (HTA } \\
\text { body) }\end{array}$ & $\begin{array}{c}\text { Yr } \\
\text { (Ref) }\end{array}$ & \begin{tabular}{|l} 
Discount \\
Rate
\end{tabular} & $\begin{array}{l}\text { Sensitivity } \\
\text { Analysis }\end{array}$ & $\begin{array}{l}\text { Rationale for Discount and } \\
\text { Sensitivity rates }\end{array}$ & $\begin{array}{c}\text { Yr } \\
\text { (Ref) }\end{array}$ & Discount Rate & $\begin{array}{l}\text { Sensitivity } \\
\text { Analysis }\end{array}$ & $\begin{array}{l}\text { Rationale for } \\
\text { Discount and } \\
\text { Sensitivity rates }\end{array}$ \\
\hline Australia (PBAC) & $\begin{array}{l}2016(1) \\
2015(2) \\
2008(3) \\
2006(4) \\
2002(5) \\
1995(6)\end{array}$ & $\begin{array}{l}5 \% \text { for both } \\
\text { costs and } \mathrm{H}\end{array}$ & $\begin{array}{l}0 \% \text { and } 3.5 \% \text { (both } \\
\text { costs and benefits } \\
\text { If justified, can use } \\
\text { different rates/ time } \\
\text { varying rates }\end{array}$ & Not stated & - & - & - & - \\
\hline $\begin{array}{l}\text { Baltic-Latvia, } \\
\text { Lithuania, Estonia } \\
\text { (experts from health } \\
\text { authorities) } \\
\end{array}$ & $2002(7)$ & $\begin{array}{l}5 \% \text { for both } \\
\text { costs and } \\
\text { benefits }\end{array}$ & Not stated & Not stated & - & - & - & - \\
\hline $\begin{array}{l}\text { Brazil (universities, } \\
\text { government) }\end{array}$ & $2014(8)$ & $\begin{array}{l}5 \% \text { for both } \\
\text { costs and } \\
\text { benefits }\end{array}$ & $\begin{array}{l}0 \% \text { to } 10 \% \text { for } \\
\text { both costs and } \\
\text { benefits }\end{array}$ & Not stated & - & & - & |- \\
\hline $\begin{array}{l}\text { Belgium } \\
\text { (KCE - Belgium } \\
\text { Health Care } \\
\text { Knowledge Centre) }\end{array}$ & \begin{tabular}{|l}
$2012(9)$ \\
2008 \\
$(10)$
\end{tabular} & $\begin{array}{l}3 \% \text { for costs; } \\
1.5 \% \text { for } \\
\text { benefits }\end{array}$ & $\begin{array}{l}0 \%, 3 \%, 5 \% \text { for } \\
\text { both costs and } \\
\text { benefits }\end{array}$ & $\begin{array}{l}\text { Discount Rate: Lower rate for } \\
\text { benefits than costs to avoid } \\
\text { underweighting future benefits } \\
\text { Sensitivity Analysis: 0\% and 5\% to } \\
\text { judge relative importance of using } \\
\text { different rates; 3\% to compare with } \\
\text { other countries }\end{array}$ & I- & - & - & - \\
\hline Canada (CADTH) & $\begin{array}{l}2017 \\
(11)\end{array}$ & $\begin{array}{l}1.5 \% \text { for both } \\
\text { costs and } \\
\text { benefits }\end{array}$ & $\begin{array}{l}0 \% \text { and } 3 \% \text { for } \\
\text { both costs and } \\
\text { benefits } \\
5 \% \text { (if desired) }\end{array}$ & $\begin{array}{l}\text { Discount Rate: Rate reflects real rate of } \\
\text { interest on government bonds faced by } \\
\text { higher authority that funds the health care } \\
\text { system. } \\
\text { Sensitivity Analysis: } 0 \% \text { to show } \\
\text { impact of discounting; } 3 \% \text { as upper } \\
\text { bound; 5\% to compare with ICERs } \\
\text { under old guidelines }\end{array}$ & $\begin{array}{l}2006(12) \\
1997(13) \\
1996(14)\end{array}$ & $\begin{array}{l}5 \% \text { for both } \\
\text { costs and } \\
\text { benefits }\end{array}$ & $\begin{array}{l}-0 \% \text { and } 3 \% \\
(1997 \text { and } \\
2006 \\
\text { report) } \\
0 \% \text { and varied } \\
\text { rated (1996 } \\
\text { report) }\end{array}$ & $\begin{array}{l}\text { Sensitivity Analysis: } \\
0 \% \text { to show impact of } \\
\text { discounting; 3\% to } \\
\text { compare with } \\
\text { published evaluations } \\
\text { using 3\% discount } \\
\text { rates. }\end{array}$ \\
\hline $\begin{array}{l}\text { China (universities, } \\
\text { government, } \\
\text { hospitals) }\end{array}$ & $\begin{array}{l}2010 \\
(15)\end{array}$ & $\begin{array}{l}1 \text {-yr rate for } \\
\text { treasury notes or } \\
\text { use standard rates } \\
\text { for both costs and } \\
\text { benefits }\end{array}$ & $\begin{array}{l}0 \% \text { to } 8 \% \text { for both } \\
\text { costs and benefits }\end{array}$ & Not stated & & - & - & - \\
\hline $\begin{array}{l}\text { Croatia (Agency for } \\
\text { Quality and } \\
\text { Accreditation in } \\
\text { Health Care) }\end{array}$ & 2011(16) & $\begin{array}{l}5 \% \text { for both } \\
\text { costs and } \\
\text { benefits }\end{array}$ & $\begin{array}{l}\text { Rates from } 3 \% \text { to } \\
10 \% \text { \& differential } \\
\text { rates for costs \& }\end{array}$ & Not stated & & & & \\
\hline
\end{tabular}




\begin{tabular}{|c|c|c|c|c|c|c|c|c|}
\hline \multicolumn{5}{|c|}{ Cuirent Rate } & \multicolumn{4}{|c|}{ Previous Rate (if different from Current Rate) } \\
\hline $\begin{array}{l}\text { Country (HTA } \\
\text { body) }\end{array}$ & $\begin{array}{c}\text { Yr } \\
\text { (Ref) }\end{array}$ & $\begin{array}{l}\text { Discount } \\
\text { Rate }\end{array}$ & $\begin{array}{l}\text { Sensitivity } \\
\text { Analysis }\end{array}$ & $\begin{array}{l}\text { Rationale for Discount and } \\
\text { Sensitivity rates }\end{array}$ & $\begin{array}{c}\text { Yr } \\
\text { (Ref) }\end{array}$ & Discount Rate & $\begin{array}{l}\text { Sensitivity } \\
\text { Analysis }\end{array}$ & $\begin{array}{l}\text { Rationale for } \\
\text { Discount and } \\
\text { Sensitivity rates }\end{array}$ \\
\hline & & & benefits & & & & & \\
\hline \begin{tabular}{|l|} 
Czech Republic (State \\
Institute for Drug \\
Control) \\
\end{tabular} & $\begin{array}{l}2017 \\
(17)\end{array}$ & $\begin{array}{l}3 \% \text { for both } \\
\text { costs and } \\
\text { benefits }\end{array}$ & - $0 \%$ and $5 \%$ & Not stated & - & - & - & - \\
\hline $\begin{array}{l}\text { Columbia (IETS - } \\
\text { Instituto de Evaluación } \\
\text { Tecnológica en Salud) }\end{array}$ & $\begin{array}{l}2014(18, \\
19)\end{array}$ & $\begin{array}{l}5 \% \text { for both } \\
\text { costs and } \\
\text { benefits }\end{array}$ & $0 \%$ to $12 \%$ & Not stated & - & - & - & - \\
\hline $\begin{array}{l}\text { Egypt (Ministry of } \\
\text { Health, Central Admin. } \\
\text { for Pharm.Affairs, } \\
\text { General Directorate of } \\
\text { Hosp. Pharmacy } \\
\text { Pharmacoecon. Unit) }\end{array}$ & $\begin{array}{l}2013 \\
(20)\end{array}$ & $\begin{array}{l}3.5 \% \text { for both } \\
\text { costs and } \\
\text { benefits }\end{array}$ & - $2 \%$ to $6 \%$ & Not stated & - & - & - & - \\
\hline $\begin{array}{l}\text { Finland } \\
\text { (Pharmaceuticals } \\
\text { Pricing Board (in co- } \\
\text { operation with the } \\
\text { Social Insurance } \\
\text { Institution (Kela) and } \\
\text { the Pharma Industry) } \\
\end{array}$ & $\begin{array}{l}2017 \\
(21)\end{array}$ & $\begin{array}{l}3 \% \text { for both } \\
\text { costs and } \\
\text { benefits }\end{array}$ & $0 \%$ & Not stated & - & - & - & - \\
\hline $\begin{array}{l}\text { France (Haute } \\
\text { Autorité de Santé - } \\
\text { HAS) }\end{array}$ & $2012(22)$ & $\begin{array}{l}4 \% \text { for both costs } \\
\text { and benefits for } \\
\text { time horizons of } \\
\text { less } \\
\text { A reduction of up } \\
\text { to } 2 \% \text { thereafter }\end{array}$ & $0 \%, 3 \%$ and $6 \%$ & $\begin{array}{l}\text { Discount Rate: Relative prices of benefits } \\
\text { for community do not change over time; } \\
\text { hence, costs/benefits discounted at same } \\
\text { rate; Adopts } 2008 \text { WHO recommendation } \\
\text { that rate declines after } 30 \text { years. } \\
\text { Sensitivity Analysis: } 0 \% \text { to show impact } \\
\text { of discounting; } 3 \% \text { used to compare with } \\
\text { other jurisdictions; } 6 \% \text { as the maximum } \\
\text { social discount rate }\end{array}$ & $2004(23)$ & $\begin{array}{l}\bullet 0 \%, 3 \%, \& \\
5 \% \\
\text { Same rate for } \\
\text { costs and benefits } \\
\text { unless different } \\
\text { time preferences } \\
\text { are observed }\end{array}$ & $\begin{array}{l}\text { Various rates, } \\
\text { including } 0 \%\end{array}$ & $\begin{array}{l}\text { Sensitivity Analysis: } \\
\text { various rates to make } \\
\text { international } \\
\text { comparisons }\end{array}$ \\
\hline Germany (IQWiG) & $\begin{array}{l}2015 \\
(24) \\
2009 \\
(25)\end{array}$ & $\begin{array}{l}3 \% \text { for both } \\
\text { costs and } \\
\text { benefits }\end{array}$ & $\begin{array}{l}0 \% \text { and } 5 \% \text { (in } \\
2015 \text { report) } \\
-0 \%, 5 \%, 7 \%, 10 \% \\
\text { (in } 2009 \text { report) }\end{array}$ & & $2008(26)$ & $\begin{array}{l}5 \% \text { for both } \\
\text { costs and } \\
\text { benefits }\end{array}$ & $\begin{array}{l}0 \%, 3 \% \\
7 \%, 10 \%\end{array}$ & $\begin{array}{l}\text { Discount rate: choice } \\
\text { of rate somewhat } \\
\text { arbitrary, hence range } \\
\text { should be used }\end{array}$ \\
\hline Hungary & $\begin{array}{l}2017 \\
(27)\end{array}$ & $\begin{array}{l}3.7 \% \text { for both costs } \\
\text { and benefit }\end{array}$ & $\begin{array}{l}2 \text { to } 5 \% \text { (costs) } \\
0 \text { to } 5 \% \text { (benefits) } \\
\text { varying discount } \\
\text { rates in sensitivity } \\
\text { analysis }\end{array}$ & $\begin{array}{l}\text { Discount rate: In line with the } \\
\text { calculations based on domestic } \\
\text { empirical data } \\
\text { Sensitivity Analyses: range of rates } \\
\text { chosen to compare across jurisdictions }\end{array}$ & $2002(28)$ & $\begin{array}{l}5 \% \text { for both } \\
\text { costs and } \\
\text { benefits }\end{array}$ & $\begin{array}{l}3 \% \text { to } 6 \% \text { for } \\
\text { costs } \\
0 \% \text { to } 6 \% \text { for } \\
\text { benefits }\end{array}$ & $\begin{array}{l}\text { Sensitivity Analyses: } \\
\text { range of rates chosen to } \\
\text { compare with other } \\
\text { countries }\end{array}$ \\
\hline \begin{tabular}{|l} 
Ireland (Health \\
Information and
\end{tabular} & $\begin{array}{l}2018 \\
(29)\end{array}$ & $\begin{array}{l}5 \% \text { for both } \\
\text { costs and }\end{array}$ & $\begin{array}{l}0 \% \text { and } 10 \% \\
-\quad+-1 \% \text { in discount }\end{array}$ & $\begin{array}{l}\text { Sensitivity Analysis: } 0 \% \text { to show } \\
\text { impact of discounting; } 10 \% \text { to show }\end{array}$ & & & - & - \\
\hline
\end{tabular}




\begin{tabular}{|c|c|c|c|c|c|c|c|c|}
\hline \multicolumn{5}{|c|}{ Cuirent Rate } & \multicolumn{4}{|c|}{ Previous Rate (if different from Current Rate) } \\
\hline $\begin{array}{l}\text { Country (HTA } \\
\text { body) }\end{array}$ & $\begin{array}{c}\text { Yr } \\
\text { (Ref) }\end{array}$ & $\begin{array}{l}\text { Discount } \\
\text { Rate }\end{array}$ & $\begin{array}{l}\text { Sensitivity } \\
\text { Analysis }\end{array}$ & $\begin{array}{l}\text { Rationale for Discount and } \\
\text { Sensitivity rates }\end{array}$ & $\begin{array}{l}\text { Yr } \\
\text { (Ref) }\end{array}$ & Discount Rate & $\begin{array}{l}\text { Sensitivity } \\
\text { Analysis }\end{array}$ & \begin{tabular}{|l} 
Rationale for \\
Discount and \\
Sensitivity rates
\end{tabular} \\
\hline Quality Authority) & & benefits & rate, if desired & high rate of discounting & & & & \\
\hline $\begin{array}{l}\text { Israel (Ministry of } \\
\text { Health Pharmaceutical } \\
\text { Administration) }\end{array}$ & $\begin{array}{l}2010 \\
(30)\end{array}$ & $\begin{array}{l}3 \% \text { for both } \\
\text { costs and } \\
\text { benefits }\end{array}$ & Not stated & not stated & $2002(31)$ & not stated & not stated & not stated \\
\hline $\begin{array}{l}\text { Italy (Italian Group } \\
\text { for } \\
\text { Pharmacoeconomic } \\
\text { Studies) } \\
\end{array}$ & $\begin{array}{l}2001 \\
(32)\end{array}$ & $\begin{array}{l}3 \% \text { for both } \\
\text { costs and } \\
\text { benefits }\end{array}$ & $\begin{array}{l}0 \% \text { to } 8 \% \text { for both } \\
\text { costs and benefits }\end{array}$ & $\begin{array}{l}\text { Discount rate: } 3 \% \text { is in line with cost- } \\
\text { opportunity, and it is more appropriate for } \\
\text { comparing the different existing studies }\end{array}$ & - & - & - & - \\
\hline $\begin{array}{l}\text { Japan (Central Social } \\
\text { Insurance Medical } \\
\text { Council (Chuikyo) } \\
\end{array}$ & $\begin{array}{l}2016(33, \\
34)\end{array}$ & $\begin{array}{l}2 \% \text { for both } \\
\text { costs and } \\
\text { benefits }\end{array}$ & $\begin{array}{l}0 \% \text { to } 4 \% \text { for both } \\
\text { costs and benefits }\end{array}$ & not stated & $F$ & F & - & - \\
\hline $\begin{array}{l}\text { Malaysia (Ministry of } \\
\text { Health Malaysia, } \\
\text { Pharmaceutical } \\
\text { Services Division) }\end{array}$ & $\begin{array}{l}2012 \\
(35)\end{array}$ & $\begin{array}{l}3 \% \text { should be } \\
\text { adopted for both } \\
\text { costs and benefits }\end{array}$ & - $0 \%$ and $5 \%$ & not stated & - & - & - & F \\
\hline $\begin{array}{l}\text { Mexico (General } \\
\text { Health Council. } \\
\text { CANIFARMA, } \\
\text { AMID, AMIIF, } \\
\text { Pharmaceutical } \\
\text { Industry, \& academics } \\
\end{array}$ & $\begin{array}{l}2015 \\
(36)\end{array}$ & $\begin{array}{l}5 \% \text { for both } \\
\text { costs and } \\
\text { benefits }\end{array}$ & not stated & not stated & 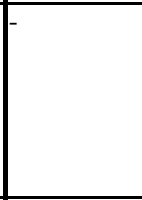 & 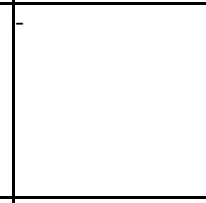 & t & \\
\hline $\begin{array}{l}\text { Netherlands (ZIN - } \\
\text { Zorginstituut } \\
\text { Nederland/National } \\
\text { Health Care Institute, } \\
\text { successor to CVZ - } \\
\text { National Health Care } \\
\text { Institute in the } \\
\text { Netherlands) }\end{array}$ & $\begin{array}{l}2016 \\
(37) ; \\
2006 \\
(38)\end{array}$ & $\begin{array}{l}4 \% \text { drug costs and } \\
\text { curative care } \\
1.5 \% \text { : drug } \\
\text { benefits and } \\
\text { curative care } \\
\text { Differing rates } \\
\text { for forensic } \\
\text { interventions }\end{array}$ & $\begin{array}{l}0 \% \text { for both costs and } \\
\text { benefits } \\
\text { Rates in social cost- } \\
\text { benefit analysis } \\
\text { (MKBA) applied to } \\
\text { preventive } \\
\text { interventions }\end{array}$ & $\begin{array}{l}\text { Discount Rate: } 4 \% \text { on cost based on } \\
\text { current returns on obligations and } \\
\text { literature; } 1.5 \% \text { on benefits based on } \\
\text { assumption of increasing life expectation } \\
\text { and on literature. (2006) }\end{array}$ & $1999(39)$ & $\begin{array}{l}4 \% \text { for both } \\
\text { costs and } \\
\text { benefits }\end{array}$ & $\begin{array}{l}\text { Varied rates } \\
\text { from } \\
\text { reference case } \\
\text { (not } \\
\text { specified) }\end{array}$ & $\begin{array}{l}\text { Discount rate: Based } \\
\text { on Cabinet's standpoint } \\
\text { on the reconsideration } \\
\text { of the discount rate } \\
\text { dated } 9 \text { Jan } 1995\end{array}$ \\
\hline \begin{tabular}{|l} 
New Zealand \\
(PHARMAC)
\end{tabular} & $\begin{array}{l}2015 \\
(40)\end{array}$ & $\begin{array}{l}3.5 \% \text { for both } \\
\text { costs \& benefits }\end{array}$ & - $0 \%$ and $5 \%$ & not stated & - & - & - & - \\
\hline \begin{tabular}{|l|} 
Norway (NOMA - the \\
Norwegian Medicines \\
Agency)
\end{tabular} & $\begin{array}{l}2012 \\
(41)\end{array}$ & $\begin{array}{l}4 \% \text { for both } \\
\text { costs and } \\
\text { benefits }\end{array}$ & not stated & $\begin{array}{l}\text { Discount Rate: Rate assuming that most } \\
\text { projects in the health sector are have } \\
\text { moderate systemic risk. }\end{array}$ & f & - & - & - \\
\hline $\begin{array}{l}\text { Poland (AHTA- } \\
\text { Agency for Health } \\
\text { Technology } \\
\text { Assessment) }\end{array}$ & $\begin{array}{l}2016 \\
(42) ; \\
2009 \\
(43)\end{array}$ & $\begin{array}{l}5 \% \text { for costs and } \\
3.5 \% \text { for health } \\
\text { benefits }\end{array}$ & $\begin{array}{l}0 \% \text { for both costs and } \\
\text { benefits (2016 report) } \\
5 \% \text { for costs and } \\
\text { benefits; } 0 \% \text { for costs } \\
\text { and benefits; } 0 \% \text { for } \\
\text { benefits and } 5 \% \text { for } \\
\text { costs (2009 report) }\end{array}$ & $\begin{array}{l}\text { Discount Rate: Differentiation of the } \\
\text { discount rate for costs and health benefits } \\
\text { is justified mainly due to rising social } \\
\text { expectations with regards to maintaining } \\
\text { good health, as well as time-varying } \\
\text { willingness to pay for health benefits }\end{array}$ & \begin{tabular}{|l|} 
Note: First \\
HTA \\
methodolo \\
gical \\
guideline \\
for Poland \\
was \\
released in \\
2007(in \\
polish \\
\end{tabular} & - & - & - \\
\hline
\end{tabular}




\begin{tabular}{|c|c|c|c|c|c|c|c|c|}
\hline \multicolumn{5}{|c|}{ Cuirent Rate } & \multicolumn{4}{|c|}{ Previous Rate (if different from Current Rate) } \\
\hline $\begin{array}{l}\text { Country (HTA } \\
\text { body) }\end{array}$ & $\begin{array}{c}\text { Yr } \\
\text { (Ref) }\end{array}$ & $\begin{array}{l}\text { Discount } \\
\text { Rate }\end{array}$ & $\begin{array}{l}\text { Sensitivity } \\
\text { Analysis }\end{array}$ & $\begin{array}{l}\text { Rationale for Discount and } \\
\text { Sensitivity rates }\end{array}$ & $\begin{array}{l}\text { Yr } \\
\text { (Ref) }\end{array}$ & Discount Rate & $\begin{array}{l}\text { Sensitivity } \\
\text { Analysis }\end{array}$ & $\begin{array}{l}\text { Rationale for } \\
\text { Discount and } \\
\text { Sensitivity rates }\end{array}$ \\
\hline & & & & & only) & & & \\
\hline $\begin{array}{l}\text { Portugal (Ministry of } \\
\text { Health) }\end{array}$ & $\begin{array}{l}1998 \\
(44)\end{array}$ & $\begin{array}{l}5 \% \text { for both } \\
\text { costs and } \\
\text { benefits }\end{array}$ & $\begin{array}{l}\text { o for health } \\
\text { benefits }\end{array}$ & not stated & 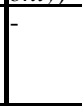 & & - & - \\
\hline $\begin{array}{l}\text { Scotland (SMC - } \\
\text { Scottish Medicines } \\
\text { Consortium) }\end{array}$ & $\begin{array}{l}2017(45) \\
; 2007(46)\end{array}$ & $\begin{array}{l}3.5 \% \text { for both } \\
\text { costs and benefits } \\
\text { (for analyses with } \\
\text { a time horizon of } \\
\text { less than } 30 \text { years) }\end{array}$ & $\begin{array}{l}0 \% \text { to } 6 \% \text { to both } \\
\text { costs and benefits }\end{array}$ & $\begin{array}{l}\text { Discount Rate: Derived from applicable } \\
\text { rates in The Treasury Green Book (47); } \\
\text { estimated from two components: 1) time } \\
\text { preference, and } \\
\text { 2) wealth effect }\end{array}$ & - & & - & \\
\hline \begin{tabular}{|l} 
Slovak Republic \\
(Ministry of Health, \\
ISPOR)
\end{tabular} & 2011(48) & $\begin{array}{l}5 \% \text { for both } \\
\text { costs and } \\
\text { benefits }\end{array}$ & not stated & not stated & 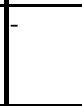 & & - & - \\
\hline \begin{tabular}{|l|} 
Slovenia (Health \\
Insurance Institute of \\
Slovenia) \\
\end{tabular} & $\begin{array}{l}2013 \\
(49)\end{array}$ & $\begin{array}{l}3 \% \text { to } 5 \% \text { for } \\
\text { costs } \\
3 \% \text { for benefits }\end{array}$ & $0 \%$ to $8 \%$ for costs & not stated & - & & - & - \\
\hline $\begin{array}{l}\text { Singapore (ACE - } \\
\text { agency for care } \\
\text { effectiveness) }\end{array}$ & $2018(50)$ & $\begin{array}{l}3 \% \text { for costs and } \\
\text { benefits }\end{array}$ & $\begin{array}{l}0 \% \text { and } 5 \% \text { for } \\
\text { both costs and } \\
\text { benefits }\end{array}$ & $\begin{array}{l}\text { Discount rate: Based on return on } \\
\text { risk-free government bonds } \\
\text { Sensitivity Analyses: } 0 \% \text { and 5\% to test } \\
\text { impact of chosen discount rate on ICER }\end{array}$ & - & 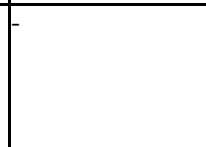 & - & - \\
\hline \begin{tabular}{|l} 
Ppain (various \\
universities and public \\
agencies)
\end{tabular} & $\begin{array}{l}2010 \\
(51)\end{array}$ & $\begin{array}{l}3 \% \text { to both costs } \\
\text { and benefits }\end{array}$ & $\begin{array}{l}0 \% \text { to } 5 \% \text { for costs } \\
\text { and benefits }\end{array}$ & $\begin{array}{l}\text { Discount rate: Constant rate to avoid } \\
\text { logical inconsistency in the analysis. } \\
\text { Sensitivity Analysis: } 0 \% \text { to } 5 \% \text { to } \\
\text { compare with other studies }\end{array}$ & - & - & - & - \\
\hline $\begin{array}{l}\text { South Africa (National } \\
\text { Department of Health) }\end{array}$ & $2012(52)$ & $\begin{array}{l}5 \% \text { for both } \\
\text { costs and } \\
\text { benefits }\end{array}$ & $\begin{array}{l}0 \% \text { to } 10 \% \text { for } \\
\text { both costs and } \\
\text { benefits }\end{array}$ & $\begin{array}{l}\text { Sensitivity Analysis: To measure } \\
\text { impact of discount rate }\end{array}$ & - & & - & - \\
\hline $\begin{array}{l}\text { Sweden (TLV - } \\
\text { Dental \& } \\
\text { Pharm.Benefit } \\
\text { Agency) } \\
\end{array}$ & $2017(53)$ & $\begin{array}{l}3 \% \text { for both } \\
\text { costs and } \\
\text { benefits }\end{array}$ & $\begin{array}{l}0 \% \text { to } 5 \% \text { for both } \\
\text { costs and benefits }\end{array}$ & not stated & - & - & - & - \\
\hline $\begin{array}{l}\text { Taiwan (TaSPOR, - } \\
\text { Taiwan Society for } \\
\text { Pharmacoeconomic } \\
\text { and Benefits } \\
\text { Research) } \\
\end{array}$ & $\begin{array}{l}2006 \\
(54)\end{array}$ & $\begin{array}{l}5 \% \text { for both } \\
\text { costs and } \\
\text { benefits }\end{array}$ & $\begin{array}{l}0 \% \text { to } 3 \% \text { for both } \\
\text { costs and benefits }\end{array}$ & $\begin{array}{l}\text { Discount Rate: Based on long- term } \\
\text { market interest rate }\end{array}$ & - & - & - & - \\
\hline $\begin{array}{l}\text { Thailand (Health } \\
\text { Intervention and } \\
\text { Technology } \\
\text { Assessment Program) }\end{array}$ & $\begin{array}{l}2008 \\
(55)\end{array}$ & $\begin{array}{l}3 \% \text { for both } \\
\text { costs and } \\
\text { benefits }\end{array}$ & $\begin{array}{l}0 \% \text { to } 6 \% \text { for both } \\
\text { costs and benefits }\end{array}$ & $\begin{array}{l}\text { Discount Rate: While recognizing } \\
\text { criticism of both arguments for uniform } \\
\text { and differential rate, Thai Health } \\
\text { Technology Assessment Guideline } \\
\text { opted for uniform rate as most } \\
\text { international guidelines use }\end{array}$ & & & - & - \\
\hline
\end{tabular}




\begin{tabular}{|c|c|c|c|c|c|c|c|c|}
\hline \multicolumn{5}{|c|}{ Cuirent Rate } & \multicolumn{4}{|c|}{ Previous Rate (if different from Current Rate) } \\
\hline $\begin{array}{l}\text { Country (HTA } \\
\text { body) }\end{array}$ & $\begin{array}{c}\text { Yr } \\
\text { (Ref) }\end{array}$ & $\begin{array}{l}\text { Discount } \\
\text { Rate }\end{array}$ & $\begin{array}{l}\text { Sensitivity } \\
\text { Analysis }\end{array}$ & $\begin{array}{l}\text { Rationale for Discount and } \\
\text { Sensitivity rates }\end{array}$ & $\begin{array}{c}\mathrm{Yr} \\
\text { (Ref) }\end{array}$ & Discount Rate & $\begin{array}{l}\text { Sensitivity } \\
\text { Analysis }\end{array}$ & $\begin{array}{l}\text { Rationale for } \\
\text { Discount and } \\
\text { Sensitivity rates }\end{array}$ \\
\hline & & & & uniform discount rate. & & & & \\
\hline UK (NICE) & \begin{tabular}{|l}
2013 \\
$(56)$ \\
2009 \\
$(57)$ \\
2008 \\
$(58)$ \\
2004 \\
$(59)$
\end{tabular} & $\begin{array}{l}3.5 \% \text { for both } \\
\text { costs and } \\
\text { benefits }\end{array}$ & $\begin{array}{l}\text { Lower rate of } 1.5 \% \\
\text { may be used if highly } \\
\text { likely that there are } \\
\text { long-term health } \\
\text { benefits ( } 2013 \text { report) } \\
0 \% \text { to } 6 \% \text { for both } \\
\text { costs and benefits } \\
\text { (2004 report) }\end{array}$ & $\begin{array}{l}\text { Discount rate: Based on } \\
\text { recommendations of the UK Treasury for } \\
\text { the discounting of costs. }\end{array}$ & - & - & - & - \\
\hline $\begin{array}{l}\text { US (Second Panel on } \\
\text { Cost-Effectiveness in } \\
\text { Health and Medicine) }\end{array}$ & $\begin{array}{l}2016 \\
60)\end{array}$ & $\begin{array}{l}3 \% \text { for both } \\
\text { costs and } \\
\text { benefits }\end{array}$ & $\begin{array}{l}0 \% \text { and } 7 \% \text { for } \\
\text { both costs and } \\
\text { benefits } \\
\text { Recommend using } \\
\text { reasonable range of } \\
\text { rates, along with more } \\
\text { research on the topic } \\
\text { of using different } \\
\text { discount rates for } \\
\text { costs and benefits in } \\
\text { the CEA }\end{array}$ & $\begin{array}{l}\text { Discount Rate: } 3 \% \text { was chosen to } \\
\text { promote comparability across studies; } \\
\text { furthermore, considered most appropriate } \\
\text { real discount rate for cost- effectiveness } \\
\text { given available data on real economic } \\
\text { growth and corresponding estimates of the } \\
\text { real consumption rate of interest }\end{array}$ & $\begin{array}{l}1996(61) \\
\text { (original } \\
\text { Panel on } \\
\text { Cost- } \\
\text { Effectiven } \\
\text { ess in } \\
\text { Health and } \\
\text { Medicine) }\end{array}$ & $\begin{array}{l}3 \% \text { for both } \\
\text { costs and } \\
\text { benefits }\end{array}$ & $\begin{array}{l}\bullet 5 \% \text {; } \\
\text { Other rates in } \\
\text { range of } 0 \% \text { to } \\
7 \%\end{array}$ & $\begin{array}{l}\text { Discount Rate: } \\
\text { Reflects rate of return } \\
\text { on riskless, long-term } \\
\text { securities; empirical } \\
\text { evidence suggests 3\% } \\
\text { rate; time preference } \\
\text { evidence for health } \\
\text { benefits also consistent } \\
\text { with 3\% } \\
\text { Sensitivity Analyses: } \\
5 \% \text { was chosen as } \\
\text { many published CEAs } \\
\text { have used that rate; } \\
\text { range of 0\% to 7\% }\end{array}$ \\
\hline
\end{tabular}

1. Health, A. G. D. o. (2018). PBAC Guidelines |3A.1 Overview and rationale of the economic evaluation.

2. PBAC. (2015). Guidelines for preparing submissions to the Pharmaceutical Benefits Advisory Committee.

3. PBAC. (2008). Guidelines for preparing submissions to the Pharmaceutical Benefits Advisory Committee.

4. PBAC. (2002b). Guidelines for the Pharmaceutical Industry on Preparation of Submissions to the Pharmaceutical Benefits Advisory Committee. Retrieved from Australia:

5. PBAC. (2002a). Guidelines for preparing submissions to the Pharmaceutical Benefits Advisory Committee

6. PBAC. (1995). Guidelines for preparing submissions to the Pharmaceutical Benefits Advisory Committee: Clarification of technical aspects of measuring changes in costs and outcomes.

7. Behmane, D., Lambot, K., Irs, A., \& Steikunas, N. (2002). Baltic Guidance for Economic Evaluation of Pharmaceuticals (Pharmacoeconomic Analysis). Retrieved on May 29 2018 from https://www.ispor.org/PEguidelines/source/Baltic-PE-guideline.pdf

8. Methodological Guidelines Economic Evaluation of Health Technologies (2014). (2014). Retrieved from https://www.ispor.org/PEguidelines/countrydet.asp?c=32\&t=1

9. KCE. (2012). Belgian Guidelines for Economic Evaluations and Budget Impact Analyses. Retrieved from

https://kce.fgov.be/sites/default/files/atoms/files/KCE_183_economic_evaluations_second_edition_Report_update.pdf

10. KCE. (2008). Guidelines for pharmacoeconomic evaluations in Belgium. Retrieved on May 21 rst, 2018 from

https://kce.fgov.be/sites/default/files/atoms/files/d20081027327.pdf

11. CADTH. (2017). Guidelines for the Economic Evaluation of Health Technologies: Canada. Retrieved from Ottawa, Ontario:

12. CADTH. (2006). Guidelines for the Economic Evaluation of Health Technologies: Canada. Retrieved from Ottawa, Canada: 
13. CCOHTA. (1997). Guidelines for Economic Evaluation of Pharmaceuticals: Canada Retrieved from Ottawa, Canada.

14. Torrance, G. W., Blaker, D., Detsky, A., Kennedy, W., Schubert, F., Menon, D., . . Firestone, T. (1996). Canadian Guidelines for Economic Evaluation of Pharmaceuticals. Pharmacoeconomics, 9(6), 535-559.

15. Summary of the Draft China Guidelines for Pharmacoeconomic Evaluations. (2010). Retrieved on May $28^{\text {th }}, 2018$ from https://www.ispor.org/workpaper/ispor_comments/China-Guidelines-for-Pharmacoeconomic-Evaluations-Summary_for-Website.pdf

16. The Agency for Quality and Accreditation in HealthCare, Croatia (2011). The Croatian Guideline for Health Technology Assessment. Retrieved on May 20th, 2018 from http://studylib.net/doc/5880509/agency-for-quality-and-accreditation-in-health-care--croatia

17. Cost-effectiveness Guidelines (May 2017). Retrieved from https://www.ispor.org/PEguidelines/countrydet.asp?c=47\&t=2

18. Faira, R. M. A. (2014). Guidelines for the economic evaluation of healthcare technologies in Colombia: technical support documents. . Retrieved from Bogotá D.C.:

19. IETS. (2014). Manual para la elaboraci $\tilde{A}^{3} \mathrm{n}$ de evaluaciones econ $\tilde{A}^{3}$ micas en salud (2014) Guidelines for the Development of Health Economic Evaluations. Retrieved from https://www.ispor.org/PEguidelines/countrydet.asp?c=43\&t=1

20. Ministry of Health and Population Central Administration for Pharmaceutical Affairs, G. D. o. H. P., Pharmacoeconomic Unit. (2013). Guidelines for Reporting Pharmacoeconomic Evaluations. Retrieved from Egypt:

21. Hintalautakunta, L. Preparing a Health Economic Evaluation to be Attached to the Application for Reimbursement Status and Wholesale Price for a Medicinal Product. Retrieved on May 15 $5^{\text {th }}, 2018$ from http://www.hila.fi/c/document_library/get_file?folderId=1133981\&name=DLFE-9844.pdf

22. HAS. (2012). Choices in Methods for Economic Evaluation. Retrieved on May 28 ${ }^{\text {th }}, 2018$ from https://www.has-sante.fr/portail/jcms/r_1499251/en/choices-in-methods-foreconomic-evaluation

23. CES. (2004). French Guidelines for the Economic Evaluation of Health Care Technologies. Retrieved on May $10^{\text {th }}, 2018$ from http://www.cesasso.org/docs/France_Guidelines_HE_Evaluation.PDF

24. IQWiG. (2015). General Methods. Retrieved on May $3^{\text {rd }}$, 2018 from https://www.iqwig.de/download/IQWiG_General_Methods_Version_\%204-2.pdf

25. IQWiG. (2009). General Methods for the Assessment of the Relation of Benefits to Cost. Retrieved on May $3^{\text {rd }}, 2018$ from https://www.iqwig.de/download/General_Methods_for_the_Assessment_of_the_Relation_of_Benefits_to_Costs.pdf

26. IQWiG. (2008). Methods for Assessment of the Relation of Benefits to Costs in the German Statutory Health Care System. Retrieved on May $10^{\text {th }}$, 2018 from https://www.iqwig.de/download/08-10-14_Draft_Methods_of_the_Relation_of_Benefits_to_Costs_v_1_1.pdf

27. Doczy, V., Dozsa, C., Dudas, D., Huszti, Z., Juhasz, J., Kovi, R., . . Nemeth, B. (2017). Professional Healthcare Guideline on the Methodology of Health Technology Assessment. GYÓGYSZEREINK, 67(1), 23.

28. Szende, Á., Mogyorósy, Z., Muszbek, N., Nagy, J., Pallos, G., \& Dözsa, C. (2014). Methodological guidelines for conducting economic evaluation of healthcare interventions Hungary: a Hungarian proposal for methodology standards. The European Journal of Health Economics, 3(3), 196-206. doi:10.1007/s10198-002-0109-6

29. HIQA. (2018). Guidelines for the Economic Evaluation of Health Technologies in Ireland. Retrieved on May 21rst, from https://www.hiqa.ie/system/files/Revised_Economic_Guidelines_posted_100714.pdf

30. Guidelines for the submission of a request to include a pharmaceutical product in the national list of health services. (2010). Retrieved on May 1rst, 2018 from https://www.ispor.org/PEguidelines/source/Israel-Guidelines-for-submission_2010.pdf

31. Guidelines for the submission of a request to include a pharmaceutical product in the national list of health service--Israel. (2002).

32. Carpi, S., Ceci, A., Terranova, L., Merlo, F., \& Mantovani, L. (2001). Guidelines for Economic Evaluations in Italy: Recommendations from the Italian Group of Pharmacoeconomic Studies. Drug Information Journal, 35, 189-201.

33. Study Team for "Establishing Evaluation Methods, D. S., and Assessment Systems Toward the Application of Economic Evaluation of Healthcare Technologies to Governmental Policies". (2016). Guideline for Preparing Cost-Effectiveness Evaluation to the Central Social Insurance Medical Council.

34. Shiroiwa, T., Fukuda, T., Ikeda, S., Takura, T., \& Moriwaki, K. (2017). Development of an Official Guideline for the Economic Evaluation of Drugs/Medical Devices in Japan. Value Health, 20(3), 372-378. doi:10.1016/j.jval.2016.08.726

35. Ministry of Health Malaysia, P. S. D. (2012). Pharmacoeconomic Guideline for Malaysia. Retrieved from Malaysia:

36. ISPOR. (2015). Economic Assessment Study Guideline for Updating The National Formulary in Mexico (2015). Retrieved from https://www.ispor.org/PEguidelines/countrydet.asp?c=37\&t=1

37. ZIN. (2016). Guideline for Economic Evaluations in Healthcare. Retrieved on May $5^{\text {th }}, 2018$ from https://www.ispor.org/PEguidelines/source/Netherlands_Guideline_for_economic_evaluations_in_healthcare.pdf: 
38. CVZ. (2006). Guidelines for Pharmacoeconomic Research. Retrieved from

https://www.ispor.org/PEguidelines/source/Netherlands_Guideline_for_economic_evaluations_in_healthcare.pdf

39. CVZ. (1999). Dutch Guidelines for Pharmacoeconomic Research.

40. PHARMAC. (2015). Prescription for Pharmacoeconomic Analysis: Methods for Cost-Utility Analysis. Retrieved on May 22nd, 2018 from https://www.pharmac.govt.nz/medicines/how-medicines-are-funded/economic-analysis/pfpa/:

41. NOMA. (2012). Guidelines on how to conduct pharmacoeconomic analysis. Retrieved on May 19th, 2018 from https://legemiddelverket.no/Documents/English/Price\%20and\%20reimbursement/Application\%20for\%20reimbursement/Pharmacoeconomic\%20guidelines\%20$\% 20$ Norway.pdf

42. AOTMiT. (2016). Health Technology Assessment Guidelines. Retrieved from Warsaw, Poland.:

43. AOTMiT. (2009). Guidelines for Conducting Health Technology Assessment (HTA)..:

44. Guidelines for Economic Drug Evaluation Studies. (1998). Portugal.

45. SMC. (2017). Guidance to Manufacturers for Completion of Summary Information for Submitting Patient Groups Form. Retrieved from Scotland

46. SMC. (2007). Guidance to Manufacturers for Completion of New Product Assessment Form (NPAF). Retrieved from Scotland:

47. Treasury, H. (2018). The Green Book: Central Government Guidance on Appraisal and Evaluation. Retrieved from UK:

48. ISPOR. (2011). Pharmacoeconomic Guidelines Key Features: Slovak Republic. Retrieved from https://www.ispor.org/PEguidelines/countrydet.asp?c=35\&t=1

49. ISPOR. (2013). Pharmacoeconomic Guidelines Key Features: Slovenia. Retrieved from https://www.ispor.org/PEguidelines/countrydet.asp?c=42\&t=1

50. ACE. (2018). Drug Evaluation Methods and Process Guide. Retrieved on May 10 ${ }^{\text {th }}, 2018$ from http://www.gear4health.com/uploads/files/file-18-5ad56a888ba8e.pdf

51. Lopez-Bastida, J., Oliva, J., Antonanzas, F., Garcia-Altes, A., Gisbert, R., Mar, J., \& Puig-Junoy, J. (2010). Spanish recommendations on economic evaluation of health technologies. Eur J Health Econ, 11(5), 513-520. doi:10.1007/s10198-010-0244-4

52. Guidelines for Pharmacoeconomic Submissions. (2012). Republic of South Africa

53. ISPOR. (2018). Pharmacoeconomic Guidelines Key Features: Sweden. Retrieved from https://www.ispor.org/PEguidelines/countrydet.asp?c=21\&t=1

54. TaSPOR. (2006). Guidelines of Methodological Standards for Pharmacoeconomic Evaluations in Taiwan. Retrieved on May $14^{\text {th }}$, 2018 from https://www.ispor.org/PEguidelines/source/2006_PEG_EN_2009.pdf

55. Permsuwan, U., Guntawongwan, K., \& Buddhawongsa, P. (2008). Handling time in economic evaluation studies. Journal of the Medical Association of Thailand, 91(Suppl 2), S53.

56. National Institute for Health and Clinical Guidance. (2013). Guide to the methods of technology appraisal 2013. London: NICE.

57. National Institute for Health and Clinical Guidance. (2009). The Guidelines Manual: Appendices. London: NICE.

58. National Institute for Health and Clinical Guidance. (2008). Guide to the Methods of Technology Appraisal. London: NICE.

59. National Institute for Health and Clinical Excellence. (2004). Guide to Methods of Technology Appraisal. London: NICE.

60. Sanders, G. D., Neumann, P. J., Basu, A., Brock, D. W., Feeny, D., Krahn, M., . . Ganiats, T. G. (2016). Recommendations for Conduct, Methodological Practices, and Reporting of Cost-effectiveness Analyses: Second Panel on Cost-Effectiveness in Health and Medicine. JAMA, 316(10), 1093-1103. doi:10.1001/jama.2016.12195

61. Weinstein, M. C., Siegel, J. E., Gold, M. R., Kamlet, M. S., \& Russell, L. B. (1996). Recommendations of the Panel on Cost-Effectiveness in Health and Medicine. JAMA, 296(15), 6

Note: This table is updated as of May 25, 2020 and is limited to methodological guidelines available in the English language. 
Table 2: Calculations of Calibration factor:

\begin{tabular}{|c|c|c|c|c|}
\hline \multirow{2}{*}{$\begin{array}{c}\text { Benefit Cost Scenarios } \\
\text { Year } \\
\end{array}$} & \multicolumn{4}{|c|}{ efit and Decreasing Cost Scenario (1.5\% discount rate) } \\
\hline & $\begin{array}{c}\text { Benefit } \\
\text { (QALYs) }\end{array}$ & Costs & $\begin{array}{l}\text { iscounted } \\
\text { QALYs }\end{array}$ & Discounted Costs \\
\hline 1 & 0.25 & $\$ 3,125$ & 0.2463 & $\$ 3,079$ \\
\hline 2 & 0.25 & $\$ 3,125$ & 0.2427 & $\$ 3,033$ \\
\hline 3 & 0.25 & $\$ 0$ & 0.2391 & $\$ 0$ \\
\hline 4 & 0.25 & $\$ 0$ & 0.2355 & $\$ 0$ \\
\hline 5 & 0.25 & $\$ 0$ & 0.2321 & $\$ 0$ \\
\hline Discount rate & & & $1.5 \%$ & $1.5 \%$ \\
\hline Incremental totals & 1.2500 & $\$ 6,250$ & & \\
\hline Present Values (PV) & & & 1.1957 & $\$ 6,112$ \\
\hline $\begin{array}{l}\text { ICER=PV of cost /PV } \\
\text { of benefit }\end{array}$ & & & & $\$ 5,112 / \mathrm{QALY}$ \\
\hline $\begin{array}{l}\text { Calibration Factor for } \\
\text { ICER }=\$ 5,000\end{array}$ & & & & $\begin{array}{c}1.0224 \\
(=\$ 5,112 / \$ 5.000)\end{array}$ \\
\hline Calibrated ICER Value & & & & $\$ 5,000 / \mathrm{QALY}$ \\
\hline
\end{tabular}


Table 3: Parameter levels for incremental benefit function by starting value and by benefit profile over a ten-year time horizon

\begin{tabular}{|l|l|l|l|l|l|}
\hline \multicolumn{7}{|l|}{ Increasing Incremental Benefit Function } \\
\hline Initial incremental benefit & 0.0500 & 0.1000 & 0.1500 & 0.2000 & 0.2500 \\
\hline value of parameter $a$ & -0.4000 & -1.3500 & -1.9000 & -2.3000 & -2.7000 \\
\hline & Decreasing Incremental Benefit Function \\
\hline Initial incremental benefit & 0.0500 & 0.1000 & 0.1500 & 0.2000 & 0.2500 \\
\hline $\begin{array}{l}\text { Decreasing incremental } \\
\text { benefit parameter }\end{array}$ & $\mathrm{n} / \mathrm{a}$ & -1.8000 & -1.1000 & -0.7000 & -1.8000 \\
\hline
\end{tabular}


Table 4: Example of Incremental benefit profiles for a ten-year time horizon

\begin{tabular}{|l|l|l|l|l|l|l|l|l|l|l|l|}
\hline Year & 1 & 2 & 3 & 4 & 5 & 6 & 7 & 8 & 9 & 10 \\
\hline & \multicolumn{80}{|c|}{ Annual Incremental Benefit } \\
\hline Constant Benefit & 0.2500 & 0.2500 & 0.2500 & 0.2500 & 0.2500 & 0.2500 & 0.2500 & 0.2500 & 0.2500 & 0.2500 \\
\hline Decreasing benefit & 0.0996 & 0.0582 & 0.0514 & 0.0502 & 0.0500 & 0.0500 & 0.0500 & 0.0500 & 0.0500 & 0.0500 \\
\hline Increasing benefit & 0.1023 & 0.2490 & 0.3964 & 0.4683 & 0.4914 & 0.4977 & 0.4994 & 0.4998 & 0.5000 & 0.5000 \\
\hline
\end{tabular}


Table 5: Parameter values for increasing and decreasing benefits by time horizon

\begin{tabular}{|r|l|l|}
\hline \multicolumn{1}{|c|}{$\begin{array}{c}\text { Time } \\
\text { Horizon }\end{array}$} & & \\
\hline 20 & 0.1800 & 0.3100 \\
\hline 15 & 0.1764 & 0.3038 \\
\hline 10 & 0.1620 & 0.2790 \\
\hline 5 & 0.1530 & 0.2635 \\
\hline
\end{tabular}


Figure 1. Constant Benefits and Costs Front-Loaded During First Two Years

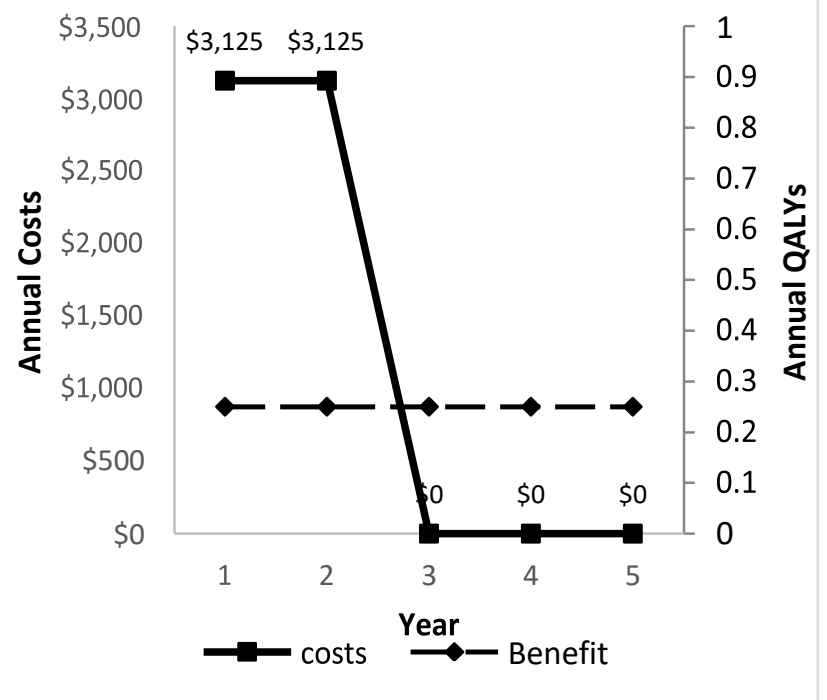


Figure 2. Constant Costs with Increase in Benefits over Time

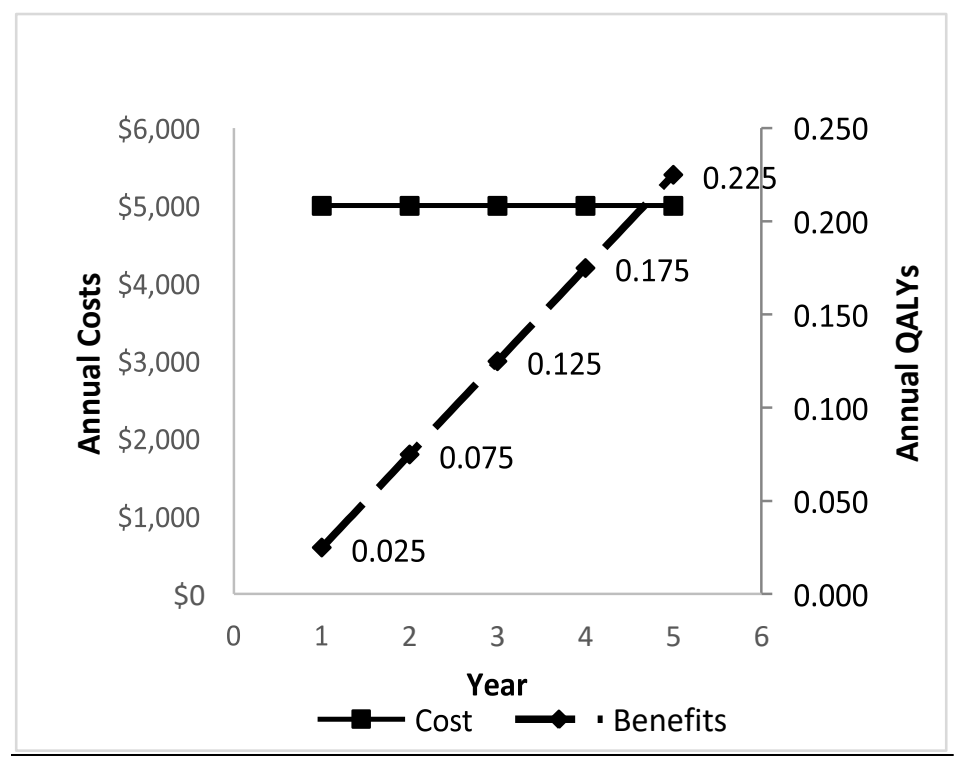


Appendix A

Table 1A: ICER- Declining Cost and Constant Benefit

\begin{tabular}{|c|c|c|c|c|c|c|c|c|c|c|c|c|}
\hline \multirow{2}{*}{\begin{tabular}{|l|} 
Time Horizon \\
Discount Rates \\
\end{tabular}} & \multicolumn{4}{|c|}{5} & \multicolumn{4}{|c|}{10} & \multicolumn{4}{|c|}{20} \\
\hline & $1.500 \%$ & $3.000 \%$ & $4.000 \%$ & $5.000 \%$ & $1.500 \%$ & $3.000 \%$ & $4.000 \%$ & $5.000 \%$ & $1.500 \%$ & $3.000 \%$ & $4.000 \%$ & $5.000 \%$ \\
\hline REF ICER @ 1.5\% & \multicolumn{4}{|c|}{ ICER } & \multicolumn{4}{|c|}{ ICER } & \multicolumn{4}{|c|}{ ICER } \\
\hline$\$ 30,000$ & $\$ 30,000$ & $\$ 30,650$ & $\$ 31,079$ & $\$ 31,505$ & \begin{tabular}{|l|l|}
$\$ 30,000$ \\
\end{tabular} & $\$ 31,730$ & $\$ 32,893$ & $\$ 34,062$ & $\$ 30,000$ & $\$ 33,869$ & $\$ 36,547$ & $\$ 39,291$ \\
\hline$\$ 35,000$ & $\$ 35,000$ & \$35,758 & $\$ 36,259$ & $\$ 36,756$ & \$35,000 & $\$ 37,019$ & $\$ 38,375$ & $\$ 39,739$ & $\$ 35,000$ & \$39,514 & $\$ 42,638$ & $\$ 45,840$ \\
\hline$\$ 40,000$ & $\$ 40,000$ & \begin{tabular}{|l|l|}
$\$ 40,867$ \\
\end{tabular} & $\$ 41,439$ & \begin{tabular}{|l|}
$\$ 42,007$ \\
\end{tabular} & \$\$\$ & $\$ 42,307$ & $\$ 43,858$ & $\$ 45,416$ & $\$ 40,000$ & $\begin{array}{l}\$ 45,159 \\
\end{array}$ & $\$ 48,729$ & $\$ 52,388$ \\
\hline$\$ 45,000$ & $\$ 45,000$ & $\$ 45,975$ & $\$ 46,619$ & $\$ 47,258$ & $\$ 45,000$ & $\$ 47,595$ & $\$ 49,340$ & $\$ 51,093$ & $\$ 45,000$ & $\$ 50,804$ & $\$ 54,820$ & $\$ 58,937$ \\
\hline$\$ 50,000$ & $\$ 50,000$ & $\$ 51,083$ & $\$ 51,799$ & $\$ 52,509$ & $\$ 50,000$ & $\$ 52,884$ & $\$ 54,822$ & $\$ 56,770$ & $\$ 50,000$ & $\begin{array}{l}56,449 \\
\end{array}$ & 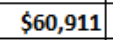 & $\$ 65,485$ \\
\hline$\$ 55,000$ & $\$ 55,000$ & $\$ 56,192$ & $\$ 56,979$ & $\$ 57,760$ & $\$ 55,000$ & $\$ 58,172$ & $\$ 60,304$ & $\$ 62,447$ & $\$ 55,000$ & $\begin{array}{l}\$ 62,094 \\
\end{array}$ & $\$ 67,002$ & $\$ 72,034$ \\
\hline$\$ 60,000$ & $\$ 60,000$ & $\$ 61,300$ & $\$ 62,159$ & $\$ 63,011$ & $\$ 60,000$ & $\$ 63,461$ & $\$ 65,786$ & $\$ 68,124$ & $\$ 60,000$ & $\$ 67,739$ & $\$ 73,093$ & $\$ 78,582$ \\
\hline \$65,000 & $\begin{array}{l}\$ 65,000 \\
\end{array}$ & \begin{tabular}{|l|l|}
$\$ 66,408$ \\
\end{tabular} & \$ $\$ 67,339$ & \begin{tabular}{|l|}
$\$ 68,262$ \\
\end{tabular} & \$ $\$ 65,000$ & $\$ 688,749$ & $\$ \$ \$ 11,269$ & $\$ 73,801$ & $\$ 65,000$ & \$\$73,384 & \$79,184 & $\$ 85,131$ \\
\hline$\$ 70,000$ & $\$ \mathbf{7 0 , 0 0 0}$ & $\$ 71,517$ & $\$ 72,519$ & $\$ 73,513$ & \begin{tabular}{|l|}
$\mathbf{7} 70,000$ \\
\end{tabular} & $\$ 74,037$ & $\$ 76,751$ & & & & $\$ 85,276$ & $\$ 91,679$ \\
\hline$\$ 75,000$ & $\$ 75,000$ & \$76,625 & \$77,698 & \$78,764 & \$75,000 & $\$ 79,326$ & \$82,233 & $\$ 85,155$ & $\$ 75,000$ & \$84,673 & $\$ 91,367$ & $\$ 98,228$ \\
\hline$\$ 80,000$ & $\$ 80,000$ & $\$ 81,733$ & $\$ 82,878$ & $\$ 84,015$ & $\$ 80,000$ & $\$ 84,614$ & $\$ 87,715$ & $\$ 90,832$ & $\$ 80,000$ & $\$ 90,318$ & $\$ 97,458$ & $\$ 104,776$ \\
\hline$\$ 85,000$ & $\$ 85,000$ & $\$ 86,842$ & $\$ 88,058$ & $\$ 89,266$ & $\$ 85,000$ & $\$ 89,903$ & $\$ 93,198$ & $\$ 96,510$ & $\$ 85,000$ & $\$ 95,963$ & $\$ 103,549$ & $\$ 111,325$ \\
\hline$\$ 90,000$ & $\$ 90,000$ & \begin{tabular}{|l|l}
91,950 \\
\end{tabular} & $\$ 93,238$ & $\$ 94,516$ & $\$ \$ 90,000$ & \$95,191 & $\$ 98,680$ & $\$ 102,187$ & $\$ 90,000$ & $\$ 101,608$ & $\$ 109,640$ & $\$ 117,873$ \\
\hline$\$ 95,000$ & $\$ 95,000$ & \begin{tabular}{|l|l|}
$\$ 97,058$ \\
\end{tabular} & $\$ 98,418$ & \$99,767 & $\$ \$ 95,000$ & $\$ 100,479$ & $\$ 104,162$ & $\$ 107,864$ & $\$ 95,000$ & $\$ 107,253$ & $\$ 115,731$ & $\$ 124,422$ \\
\hline$\$ 100,000$ & $\$ 100,000$ & $\$ 102,167$ & $\$ 103,598$ & $\$ 105,018$ & $\$ 100,000$ & $\$ 105,768$ & $\$ 109,644$ & $\$ 113,541$ & $\$ 100,000$ & $\$ 112,898$ & $\$ 121,822$ & $\$ 130,970$ \\
\hline$\$ 105,000$ & $\$ 105,000$ & $\$ 107,275$ & $\$ 108,778$ & $\$ 110,269$ & $\$ 105,000$ & $\$ 111,056$ & $\$ 115,126$ & $\$ 119,218$ & $\$ 105,000$ & $\$ 118,543$ & $\$ 127,913$ & $\$ 137,519$ \\
\hline$\$ 110,000$ & $\$ 110,000$ & $\$ 112,383$ & $\$ 113,958$ & $\$ 115,520$ & $\$ 1110,000$ & $\$ 116,344$ & $\$ 120,609$ & $\$ 124,895$ & $\$ 110,000$ & $\$ 124,188$ & $\$ 134,004$ & $\$ 144,067$ \\
\hline$\$ 115,000$ & $\$ 115,000$ & $\$ 117,492$ & $\$ 119,138$ & $\$ 120,771$ & $\$ 115,000$ & $\$ 121,633$ & $\$ 126,091$ & $\$ 130,572$ & $\$ 115,000$ & $\$ 129,832$ & $\$ 140,096$ & $\$ 150,616$ \\
\hline$\$ 120,000$ & $\$ 120,000$ & $\$ 122,600$ & $\$ 124,317$ & $\$ 126,022$ & $\$ 120,000$ & $\$ 126,921$ & $\$ 131,573$ & $\$ 136,249$ & $\$ 120,000$ & $\$ 135,477$ & $\$ 146,187$ & $\$ 157,164$ \\
\hline$\$ 125,000$ & $\$ 125,000$ & $\$ 127,708$ & $\$ 129,497$ & $\$ 131,273$ & $\$ 125,000$ & $\$ 132,210$ & $\$ 137,055$ & $\$ 141,926$ & $\$ 125,000$ & $\$ 141,122$ & $\$ 152,278$ & $\$ 163,713$ \\
\hline$\$ 130,000$ & $\$ 130,000$ & $\$ 132,817$ & $\$ 134,677$ & $\$ 136,524$ & $\$ 130,000$ & $\$ 137,498$ & $\$ 142,537$ & $\$ 147,603$ & $\$ 130,000$ & $\$ 146,767$ & $\$ 158,369$ & $\$ 170,261$ \\
\hline$\$ 135,000$ & $\$ 135,000$ & $\$ 137,925$ & $\$ 139,857$ & $\$ 141,775$ & $\$ 135,000$ & $\$ 142,786$ & $\$ 148,020$ & $\$ 153,280$ & $\$ 135,000$ & $\$ 152,412$ & $\$ 164,460$ & $\$ 176,810$ \\
\hline$\$ 140,000$ & $\$ 140,000$ & $\$ 143,033$ & $\$ 145,037$ & $\$ 147,026$ & $\$ 140,000$ & $\$ 148,075$ & $\$ 153,502$ & $\$ 158,957$ & $\$ 140,000$ & $\$ 158,057$ & $\$ 170,551$ & $\$ 183,359$ \\
\hline$\$ 145,000$ & $\$ 145,000$ & $\$ 148,142$ & $\$ 150,217$ & $\$ 152,277$ & $\$ 145,000$ & $\$ 153,363$ & $\$ 158,984$ & $\$ 164,634$ & $\$ 145,000$ & $\$ 163,702$ & $\$ 176,642$ & $\$ 189,907$ \\
\hline$\$ 150,000$ & $\$ 150,000$ & $\$ 153,250$ & $\$ 155,397$ & $\$ 157,527$ & $\$ 150,000$ & $\$ 158,652$ & $\$ 164,466$ & $\$ 170,311$ & $\$ 150,000$ & $\$ 169,347$ & $\$ 182,733$ & $\$ 196,456$ \\
\hline
\end{tabular}

Table 2A: ICER- Constant Cost and Increasing Benefit

\begin{tabular}{|c|c|c|c|c|c|c|c|c|c|c|c|c|}
\hline \multirow{2}{*}{\begin{tabular}{|l|} 
Time Horizon \\
Discount Rates \\
\end{tabular}} & \multicolumn{4}{|c|}{5} & \multicolumn{4}{|c|}{10} & \multicolumn{4}{|c|}{20} \\
\hline & $500 \%$ & $3.000 \%$ & $4.000 \%$ & $5.000 \%$ & $.500 \%$ & $3.000 \%$ & $4.000 \%$ & $5.000 \%$ & $1.500 \%$ & $3.000 \%$ & $4.000 \%$ & $5.000 \%$ \\
\hline REF ICER @ 1.5\% & \multicolumn{4}{|c|}{ ICER } & \multicolumn{4}{|c|}{ ICER } & \multicolumn{4}{|c|}{ ICER } \\
\hline$\$ 30,000$ & $\$ 30,000$ & $\$ 30,263$ & $\$ 30,440$ & $\$ 30,617$ & $\$ 30,000$ & $\$ 30,330$ & $\$ 30,556$ & $\$ 30,785$ & $\$ 30,000$ & $\$ 30,377$ & $\$ 30,642$ & $\$ 30,918$ \\
\hline$\$ 35,000$ & $\$ 35,000$ & $\$ 35,307$ & $\$ 35,513$ & $\$ 35,720$ & $\$ 35,000$ & $\$ 35,385$ & $\$ 35,648$ & $\$ 35,916$ & $\$ 35,000$ & $\$ 35,440$ & $\$ 35,749$ & $\$ 36,071$ \\
\hline$\$ 40,000$ & $\$ 40,000$ & $\$ 40,351$ & $\$ 40,587$ & $\$ 40,823$ & $\$ \$ 40,000$ & $\$ 40,440$ & $\$ 40,741$ & $\$ 41,047$ & $\$ 40,000$ & $\$ 40,502$ & $\$ 40,856$ & $\$ 41,224$ \\
\hline$\$ 45,000$ & $\$ 45,000$ & $\$ 45,395$ & $\$ 45,660$ & $\$ 45,926$ & $\$ 45,000$ & $\$ 45,495$ & $\$ 45,834$ & $\$ 46,178$ & $\$ 45,000$ & $\$ 45,565$ & $\$ 45,963$ & $\$ 46,377$ \\
\hline$\$ 50,000$ & $\$ 50,000$ & $\$ 50,439$ & $\$ 50,733$ & $\$ 51,029$ & $\$ 50,000$ & $\$ 50,550$ & $\$ 50,926$ & $\$ 51,309$ & $\$ 50,000$ & $\$ 50,628$ & $\$ 51,070$ & $\$ 51,530$ \\
\hline$\$ 55,000$ & $\$ 55,000$ & $\$ 55,483$ & $\$ 55,806$ & $\$ 56,131$ & $\$ 55,000$ & $\$ 55,606$ & $\$ 56,019$ & $\$ 56,440$ & $\$ 55,000$ & $\$ 55,691$ & $\$ 56,177$ & $\$ 56,683$ \\
\hline$\$ 60,000$ & $\$ 60,000$ & $\$ 60,527$ & $\$ 60,880$ & $\$ 61,234$ & $\$ 60,000$ & $\$ 60,661$ & $\$ 61,112$ & $\$ 61,571$ & $\$ 60,000$ & $\$ 60,753$ & $\$ 61,284$ & $\$ 61,836$ \\
\hline$\$ 65,000$ & $\$ 65,000$ & $\$ 65,571$ & $\$ 65,953$ & $\$ 66,337$ & $\$ 65,000$ & $\$ 65,716$ & 204 & $\$ 66,702$ & $\$ 65,000$ & $\$ 65,816$ & $\$ 66,391$ & $\$ 66,989$ \\
\hline$\$ 70,000$ & $\$ 70,000$ & $\$ 70,615$ & 026 & 440 & $\$ 70,000$ & $\$ 70,771$ & 297 & 833 & $\$ 70,000$ & $\$ 70,879$ & $\$ 71,498$ & $\$ 72,142$ \\
\hline$\$ 75,000$ & $\$ 75,000$ & $\$ 75,658$ & $\$ 76,100$ & $\$ 76,543$ & $\$ 75,000$ & $\$ 75,826$ & $\$ 76,389$ & $\$ 76,964$ & $\$ 75,000$ & $\$ 75,942$ & $\$ 76,605$ & $\$ 77,295$ \\
\hline$\$ 80,000$ & $\$ 80,000$ & $\$ 80,702$ & $\$ 81,173$ & $\$ 81,646$ & $\$ 80,000$ & $\$ 80,881$ & $\$ 81,482$ & $\$ 82,094$ & $\$ 80,000$ & $\$ 81,005$ & $\$ 81,712$ & $\$ 82,448$ \\
\hline$\$ 85,000$ & $\$ 85,000$ & $\$ 85,746$ & $\$ 86,246$ & $\$ 86,749$ & $\$ 85,000$ & $\$ 85,936$ & $\$ 86,575$ & $\$ 87,225$ & $\$ 85,000$ & $\$ 86,067$ & $\$ 86,819$ & $\$ 87,601$ \\
\hline$\$ 90,000$ & $\$ 90,000$ & $\$ 90,790$ & $\$ 91,320$ & $\$ 91,851$ & $\$ 90,000$ & $\$ 90,991$ & $\$ 91,667$ & $\$ 92,356$ & $\$ 90,000$ & $\$ 91,130$ & $\$ 91,926$ & $\$ 92,754$ \\
\hline$\$ 95,000$ & $\$ 95,000$ & $\$ 95,834$ & $\$ 96,393$ & $\$ 96,954$ & $\$ 95,000$ & $\$ 96,046$ & $\$ 96,760$ & $\$ 97,487$ & $\$ 95,000$ & $\$ 96,193$ & $\$ 97,033$ & $\$ 97,907$ \\
\hline$\$ 100,000$ & $\$ 100,000$ & $\$ 100,878$ & $\$ 101,466$ & $\$ 102,057$ & $\$ 100,000$ & $\$ 101,101$ & $\$ 101,853$ & $\$ 102,618$ & $\$ 100,000$ & $\$ 101,256$ & $\$ 102,140$ & $\$ 103,060$ \\
\hline$\$ 105,000$ & $\$ 105,000$ & $\$ 105,922$ & $\$ 106,540$ & $\$ 107,160$ & $\$ 105,000$ & $\$ 106,156$ & $\$ 106,945$ & $\$ 107,749$ & $\$ 105,000$ & $\$ 106,319$ & $\$ 107,247$ & $\$ 108,213$ \\
\hline$\$ 110,000$ & $\$ 110,000$ & $\$ 110,966$ & $\$ 111,613$ & $\$ 112,263$ & $\$ 110,000$ & $\$ 111,211$ & $\$ 112,038$ & $\$ 112,880$ & $\$ 110,000$ & $\$ 111,381$ & $\$ 112,354$ & $\$ 113,366$ \\
\hline$\$ 115,000$ & $\$ 115,000$ & $\$ 116,010$ & $\$ 116,686$ & $\$ 117,366$ & $\$ 115,000$ & $\$ 116,266$ & $\$ 117,131$ & $\$ 118,011$ & $\$ 115,000$ & $\$ 116,444$ & $\$ 117,461$ & $\$ 118,519$ \\
\hline$\$ 120,000$ & $\$ 120,000$ & $\$ 121,053$ & $\$ 121,760$ & $\$ 122,469$ & $\$ 120,000$ & $\$ 121,321$ & $\$ 122,223$ & $\$ 123,142$ & $\$ 120,000$ & $\$ 121,507$ & $\$ 122,568$ & $\$ 123,673$ \\
\hline$\$ 125,000$ & $\$ 125,000$ & $\$ 126,097$ & $\$ 126,833$ & $\$ 127,571$ & $\$ 125,000$ & $\$ 126,376$ & $\$ 127,316$ & $\$ 128,273$ & $\$ 125,000$ & $\$ 126,570$ & $\$ 127,675$ & $\$ 128,826$ \\
\hline$\$ 130,000$ & $\$ 130,000$ & $\$ 131,141$ & $\$ 131,906$ & $\$ 132,674$ & $\$ 130,000$ & $\$ 131,431$ & $\$ 132,408$ & $\$ 133,403$ & $\$ 130,000$ & $\$ 131,632$ & $\$ 132,782$ & $\$ 133,979$ \\
\hline$\$ 135,000$ & $\$ 135,000$ & $\$ 136,185$ & $\$ 136,979$ & $\$ 137,777$ & $\$ 135,000$ & $\$ 136,486$ & $\$ 137,501$ & $\$ 138,534$ & $\$ 135,000$ & $\$ 136,695$ & $\$ 137,889$ & $\$ 139,132$ \\
\hline$\$ 140,000$ & $\$ 140,000$ & $\$ 141,229$ & $\$ 142,053$ & $\$ 142,880$ & $\$ 140,000$ & $\$ 141,541$ & $\$ 142,594$ & $\$ 143,665$ & $\$ 140,000$ & $\$ 141,758$ & $\$ 142,996$ & $\$ 144,285$ \\
\hline$\$ 145,000$ & $\$ 145,000$ & $\$ 146,273$ & $\$ 147,126$ & $\$ 147,983$ & $\$ 145,000$ & $\$ 146,596$ & $\$ 147,686$ & $\$ 148,796$ & $\$ 145,000$ & $\$ 146,821$ & $\$ 148,103$ & $\$ 149,438$ \\
\hline 150,000 & $\$ 150,000$ & $\$ 151,317$ & $\$ 152,199$ & $\$ 153,086$ & $\$ 150,000$ & $\$ 151,651$ & $\$ 152,779$ & $\$ 153,927$ & $\$ 150,000$ & $\$ 151,884$ & $\$ 153,210$ & $\$ 154,591$ \\
\hline
\end{tabular}


Ethics approval and consent to participate

N/A

Consent for publication

Yes, all conflict of interest issues have been addressed

Availability of data and materials

Full Tables $1 \mathrm{~A}$ and $2 \mathrm{~A}$ available at the following URL:

https://docs.google.com/spreadsheets/d/1FFa332qXtrtVXkdjE93ih4b4F--

PIkiC_VMER48AHos/edit\#gid=1803679095

Competing interests

N/A

Funding

N/A

Authors' contributions

All authors contributed to the writing and editing of the paper

Acknowledgements

N/A 
References:

[1] CADTH. Guidelines for the Economic Evaluation of Health Technologies: Canada (4 ${ }^{\text {th }}$ ed.). 2017. https://www.cadth.ca/sites/default/files/pdf/guidelines for the economic evaluation of health $t$ echnologies canada 4th ed.pdf Accessed 20 February 202020

[2] Tam DY, Hughes A, Fremes SE, Youn S, Hancock-Howard RL, Coyte PC, \& Wijeysundera HC. A cost-utility analysis of transcatheter versus surgical aortic valve replacement for the treatment of aortic stenosis in the population with intermediate surgical risk. The Journal of Thoracic and Cardiovascular surgery. 2018; 155(5): 1978-88.

[3] Sanders GD, Neumann PJ, Basu A, et al. Recommendations for conduct, methodological practices, and reporting of cost-effectiveness analyses: second panel on cost-effectiveness in health and medicine. JAMA, 2016; 316(10): 1093-1103.

[4] International Network of Agencies for Health Technology Assessment (INAHTA). (2018). ListS DECIT methodological guidelines. 2018. http://www.inahta.org/download/lists_decit_methodological-guidelines-3/ Accessed 20 Feb 2020

[5] Collins R, Reith C, Emberson J, Armitage J, Baigent C, Blackwell L, and Evans S. Interpretation of the evidence for the efficacy and safety of statin therapy. The Lancet. 2016; 388(10059): 253261.

[6] Luhnen M, Waffenschmidt S, Gerber-Grote A, \& Hanke G. Health economic evaluations of sofosbuvir for treatment of chronic hepatitis C: a systematic review. Applied Health Economics 
and Health Policy, 2016; 14(5): 527-543.

[7] Magnuson EA, Farkouh ME, Fuster V, Wang K, Vilain K, Li H, ... \& Abdallah M. Costeffectiveness of percutaneous coronary intervention with drug eluting stents versus bypass surgery for patients with diabetes mellitus and multivessel coronary artery disease: results from the FREEDOM trial. Circulation. 2013; 127(7): 820-831.

[8] Garnett GP, Kim JJ, French K, \& Goldie SJ. Modelling the impact of HPV vaccines on cervical cancer and screening programmes. Vaccine, 2006; 24: S178-S186.

[9] Horstink M, Tolosa E, Bonuccelli U, Deuschl G, Friedman A, Kanovsky P, ... \& Rascol O. Review of the therapeutic management of Parkinson's disease. Report of a joint task force of the European Federation of Neurological Societies and the Movement Disorder SocietyEuropean Section. Part I: early (uncomplicated) Parkinson's disease. European Journal of Neurology, 2006; 13(11): 1170-1185.

[10] Keating GM. Sorafenib: a review in hepatocellular carcinoma. Targeted oncology, 2017; 12(2): 243-53.

[11] Zhang Z, Friedmann PD, \& Gerstein DR. (2003). Does retention matter? Treatment duration and improvement in drug use. Addiction, 2003; 98(5) : 673-684.

[12] PHARMAC. Prescription for Pharmacoeconomic Analysis: Methods for Cost-Utility Analysis.2015. https://www.pharmac.govt.nz/medicines/how-medicines-arefunded/economic-analysis/pfpa/ Accessed 22 May 2020.

[13] Shiroiwa T, Fukuda T, Ikeda S, Takura T, \& Moriwaki K. Development of an Official Guideline 
for the Economic Evaluation of Drugs/Medical Devices in Japan. Value in Health, 2017; 20(3):372-378. doi:10.1016/j.jval.2016.08.726

[14] Faira RMA. (2014). Guidelines for the economic evaluation of healthcare technologies in Colombia: technical support documents. 2014. http://www.iets.org.co/manuales/Manuales/Documentos\%20tecnicos $\% 20$ en $\% 20 \mathrm{ing} 1 \% \mathrm{C} 3 \% \mathrm{~A}$ 9s.pdf Accessed 24 May 2020.

[15] NOMA. Guidelines on how to conduct pharmacoeconomic analysis. (2012). https://legemiddelverket.no/Documents/English/Price\%20and\%20reimbursement/Application\%2 0for\%20reimbursement/Pharmacoeconomic\%20guidelines\%20-\%20Norway.pdf Accessed 19 May 2020.

[16] Treasury HM. The Green Book: Central Government Guidance on Appraisal and Evaluation. 2018. https://assets.publishing.service.gov.uk/government/uploads/system/uploads/attachment_data/file/ 685903/The_Green_Book.pdf Accessed 24 May 2020.

[17] Haute Autorite de Sante. Choices in Methods for Economic Evaluation. 2012. https://www.has-sante.fr/portail/jcms/r_1499251/en/choices-in-methods-for-economicevaluation. Accessed 28 May 2020.

[18] Permsuwan U, Guntawongwan K, \& Buddhawongsa P. Handling time in economic evaluation studies. Journal of the Medical Association of Thailand, 2008; 91(Suppl 2): S53. 
[19] Agency for Quality and Accreditation in Health Care, Croatia. The Croatian Guideline for Health Technology Assessment, Process and Reporting. 1rst edition. 2011, https://aaz.hr/sites/default/files/hrvatske_smjernice_za_procjenu_zdravstvenih_tehnologija.pdf Accessed 5 June 2020

[20] O'Mahony JF, \& Paulden M NICE's selective application of differential discounting: ambiguous, inconsistent, and unjustified. Value in Health. 2014); 17(5): 493-496. doi:10.1016/j.jval.2013.02.014

[21] Carpi S, Ceci A, Terranova L, Merlo F, \& Mantovani L. Guidelines for Economic Evaluations in Italy: Recommendations from the Italian Group of Pharmacoeconomic Studies. Drug Information Journal, 2001;35: 189-201.

[22] KCE. Guidelines for pharmacoeconomic evaluations in Belgium. 2008. https://kce.fgov.be/sites/default/files/atoms/files/d20081027327.pdf Accessed 21 May 2020.

[23] Fukuda T. Guideline for Preparing Cost-Effectiveness Evaluation to the Central Social Insurance Medical Council. 2016. https://www.valueinhealthjournal.com/cms/10.1016/j.jval.2016.08.726/attachment/ab27e4c6-6c18-48e68d7f-ec4488ad3007/mmc1.pdf Accessed 22 May 2020.

[24] Doczy V, Dozsa C, Dudas D, Huszti Z, Juhasz J, Kovi R, . . Nemeth B. Professional Healthcare Guideline on the Methodology of Health Technology Assessment. GYÓGYSZEREINK, 2017; $67(1): 23$ 
[25] Weinstein MC, Siegel JE, Gold MR, Kamlet MS, \& Russell LB. Recommendations of the Panel on Cost-Effectiveness in Health and Medicine. JAMA, 1996; 296(15): 6.

[26] Microsoft Corporation. Excel for Windows v. 10.0.14393 Build 1493. 2013.

[27] Simoens S. How to assess the value of medicines?. Frontiers in pharmacology, 2010; 1: 1-9.

[28] Paulden M, Galvanni V, Chakraborty S, et al. Discounting and the Evaluation of Health Care Programs. CADTH working paper. 2016. https://www.cadth.ca/sites/default/files/pdf/CP0008_Economic_Evaluation_Guidelines_Discount Rate_Report.pdf Accessed 27 Feb 2020

[29] U.S. Office of Management and Budget. Circular no. A-94 revised [Internet]. Washington (DC): The White House; 1992 Oct 29. https://www.whitehouse.gov/omb/circulars_a094/ Accessed 28 February 2020. 